MONIKA LEWICKA

Uniwersytet Kazimierza Wielkiego w Bydgoszczy

Monika.Lewicka@ukw.edu.pl

ORCID: orcid.org/0000-0001-5685-7861

\title{
RODZINA W NAUCZANIU KARDYNALA STEFANA WYSZYŃSKIEGO. PERSPEKTYWA PEDAGOGICZNA
}

DOI: http://dx.doi.org/10.12775/SPLP.2021.009

\section{Streszczenie}

W artykule podjęta została próba ukazania rodziny w nauczaniu kardynała Stefana Wyszyńskiego z perspektywy pedagogicznej. Zaprezentowane zostało rodzicielstwo rozumiane przez prymasa jako dar i zadanie. Przedstawiono znaczenie rodziny w życiu narodowym i społecznym oraz wychowanie w rodzinie w myśli społecznej Wyszyńskiego.

Słowa kluczowe: dziecko, matka, macierzyństwo, ojciec, ojcostwo, rodzicielstwo, rodzina, rozwój, wartości, wychowanie

\section{CARDINAL STEFAN WYSZYNSKI'S TEACHING ON FAMILY: THE PEDAGOGICAL PERSPECTIVE}

\begin{abstract}
The article attempts to show the family in the teaching of Cardinal Stefan Wyszyński from a pedagogical perspective. Parenthood understood by the Primate as a gift and task was presented. The importance of the family in national and social life and upbringing in the family in Wyszyński's social thought were presented.
\end{abstract}

Keywords: child, mother, motherhood, father, fatherhood, parenting, family, development, values, education 
Naturalną potrzebą człowieka jest pragnienie doświadczania miłości i przyjaźni, bycia akceptowanym. Potrzeby takie jednostka może zrealizować w różnych społecznościach. Do takich społeczności niewątpliwie zaliczyć możemy rodzinę. Obecny w niej wymiar emocjonalny łączy w sobie indywidualność ze zbiorowością. Czynnik emocjonalny sprawia, że człowiek angażuje się w nią w sposób całościowy i trwały. To w rodzinie jednostka może zaspokoić swoje podstawowe potrzeby, m.in. poczucie bezpieczeństwa, zaufania, przywiązania, zrozumienia, lęku przed samotnością i akceptacji ${ }^{1}$.

Beatyfikacja kardynała Stefana Wyszyńskiego skłania do refleksji nad jego myślą dotyczącą kondycji rodziny. Jest próbą odczytania aktualności społecznego nauczania prymasa w teraźniejszych warunkach. Wydaje się to być szczególnie ważne, gdyż rola i znaczenie rodziny są, podobnie jak w czasach realnego socjalizmu, osłabiane przez różne czynniki, ideologie i kryzysy. Choć współczesne czasy mają inne oblicze polityczne oraz kulturowe, nauczanie Prymasa Tysiąclecia o rodzinie jest niezwykle aktualne. Analiza współczesnej rodziny - w tym jej zagrożeń i czynników wzmacniających - należy do istotnych zagadnień społecznych, kulturowych i religijnych. Rola, jaką pełni rodzina, zarówno w kontekście jednostkowym, jak i społecznym, jest niezaprzeczalna. Rozczytywanie społecznego nauczania Wyszyńskiego jest aktualne nie tylko w kręgach duszpasterskich, ale również we wspólnotach akademickich, szczególnie wśród psychologów, pedagogów, socjologów i filozofów. Troska o rodzinę wraz z obroną godności człowieka, kulturowej tożsamości narodu, stanowi główny aspekt myśli i nauczania Prymasa Tysiąclecia.

Szczególną płaszczyzną, na której spotyka się Kościół i naród jest rodzina². W okresie Wielkiej Nowenny Tysiąclecia Wyszyński wraz z całym Kościołem katolickim w Polsce wiele uwagi poświęcił małżeństwu, rodzinie i wychowaniu³. Prymas ujmował rodzinę nie tylko w aspekcie teologicznym, pastoralnym i historycznym, ale również społecznym. Podkreślał cele i zadania rodziny ukazując ją jako naturalną i trwałą społeczność, która jest niezbędna dla istnienia i rozwoju człowieka, narodu i państwa ${ }^{4}$. Wyszyński podkreślał ważność praw i obowiązków rodziny, które jego zdaniem określają rangę w społeczeństwie. Przestrzeganie tychże praw i obowiązków jako z natury przynależnych rodzinie, stwarza nie tylko

1 M.A. Roszewski, Wizja wychowania w wymiarze nauczania spolecznego Prymasa Stefana Kardynała Wyszyńskiego, „Teologia i Człowiek”, 10 (2007), s. 143.

2 J. Lewandowski, Naród w nauczaniu Kardynała Stefana Wyszyńskiego. Warszawa 1985; W. Gałązka, Małżeństwo i rodzina w nauczaniu kardynała Stefana Wyszyńskiego, ,,Studia Prymasowskie", 4 (2010), s. 127.

3 A. Skreczko, Rodzicielstwo jako dar i zadanie na podstawie nauczania Prymasa Stefana Wyszyńskiego podczas Wielkiej Nowenny Tysiaclecia, „Rocznik Teologii Katolickiej”, T. V, 2006, s. 146.

4 A. Skreczko, Troska Prymasa Tysiaclecia o rodzinę polska, ,, Rocznik Teologii Katolickiej”, Tom 1, 2002, s. 42. 
klimat pozytywnego nastawienia do rodziny, ale jednocześnie wzmacnia siłę jej społecznego oddziaływania. W sytuacji odwrotnej, gdy ma miejsce ograniczenie praw i obowiązków, prowadzić to może do zagrożenia jej autonomii i sił twórczych. Może więc okazać się nieodwracalne dla tożsamości duchowej i kulturowej narodu. Jego myślenie wynikało z patriotyzmu i pasterskiej odpowiedzialności, które potwierdzały, że bez prawidłowo funkcjonującej rodziny, nie ma przyszłości narodu. To właśnie dostrzeganie tych zagrożeń przez Wyszyńskiego budziło w nim głęboką troskę o rodzinę . Troszczył się on o nią w sposób autentyczny, wskazując za wzór wytrwania w rodzinnej szkole miłości Świętą Rodzinęe.

\section{RODZICIELSTWO JAKO DAR I ZADANIE}

Wyszyński na pierwszym miejscu stawiał obowiązki państwowe wobec rodziny. Wskazując również, że prawa matki i ojca do wychowania dzieci powinny być zawsze traktowane przez nie jako priorytetowe: „Zachęcamy Was, Najmilsze Dzieci, do spokoju, cierpliwości i do wierności obowiązkom katolika - obywatela. W dalszym ciągu Wam wyjaśniamy, co sami dobrze wiecie, że są dwie rodziny: rodzina parafialna i rodzina domowa. Ta druga rodzina, męża i żony, ma prawo decydować, jak mają być wychowywane dzieci" " . Prymas Tysiąclecia krytykował postawę rodziców polegającą na „rzucaniu” dziecka w świat zgodnie z zasadą „radź sobie”, podkreślając, że rodzice muszą zdać sobie sprawę z tego, że obowiązek i odpowiedzialność za dziecko trwa przez długi czas ${ }^{8}$. Wskazywał również, że normy moralne są przekazywane dziecku za pośrednictwem rodzicielskiego autorytetu. Poprzez właściwą postawę rodziców, dziecko uczy się podporządkowywać zasadom reprezentowanym przez swoich rodziców, ze względu na szacunek wobec nich, a nie z lęku przed ewentualną konsekwencją. W kolejnych, przyszłych sytuacjach dziecko nie ocenia warunków zdarzenia i motywów, jakimi kierował się drugi człowiek, ale patrzy na nie w kwestii zgodności lub braku z zasadami rodziców9.

W swoim nauczaniu pasterskim wiele miejsca poświęcił godności kobiety, przypisanym jej rolom i zadaniom. Macierzyństwo utożsamiał z najważniejszym jej zadaniem. Upominał się o przywrócenie kobiecie właściwej biologiczno-ducho-

\footnotetext{
A. Skreczko, dz. cyt., s. 35.

W. Gałązka., dz. cyt., s. 130.

A. Skreczko, Wkład kardynała Stefana Wyszyńskiego w organizację duszpasterstwa kobiet, „Studia Prymasowskie”, 4, 2010, s. 251, cyt. za: S. Wyszyński, Parafia i rodzina katolicka na stużbie religijnego wychowania mtodego pokolenia, w: KPP, t. IX, s. 157-158.

$8 \quad$ S . Wyszyński, Rodzice! Nadeszła Wasza godzina, Jasna Góra, 15.08.1961, KPA, t. 9, s. 32-33.

9 M.A. Roszewski, Wizja wychowania w wymiarze nauczania społecznego Prymasa Stefana Kardynała Wyszyńskiego, „Teologia i Człowiek”, 10 (2007), s. 151-152.
} 
wej i społecznej roli oraz przysługującego jej szacunku ${ }^{10}$. Mawiał, że gdy apoteozujemy macierzyństwo - odsłaniany przez to życie jako najwspanialszą filozofię rodziny ludzkiej ${ }^{11}$. Wyszyński wskazywał na szczególną cześć, jaką okazuje Matka-Kościół każdej ziemskiej matce, stawiając ludziom za wzór Maryję, której wizerunki znajdujące się w każdej świątyni katolickiej są wyrazem szacunku dla matek i oznaką afirmacji macierzyństwa ${ }^{12}$.

W jego rozważaniach możemy dostrzec niezwykły szacunek, jakim darzył kobiety, pokładał w nich również wielkie nadzieje związane z umocnieniem Kościoła i ratowaniem narodu. Macierzyńskie zadania kobiety ważne są nie tylko dla samej rodziny. „Rodzina jest najtrwalszą w dziejach społecznością. Przedziwnie skromna, malutka, jest niezwyciężoną potęgą. Zaczyna się od dwojga ludzi, męża i żony, jakże niekiedy słabych, ale jednakże powołanych do najdonioślejszego zadania na ziemi. Bo to co powstaje w rodzinie, ma olbrzymie znaczenie, nie tylko dla rodziny, ale dla narodu, dla państwa, dla Kościoła, dla całej ludzkości i jej dziejów. Dlatego wszyscy patrzą ku rodzinie z wielką ufnością i nadzieją" 13 .

Matkom stawiał też konkretne wymagania, za wzór podając Maryję ${ }^{14}$. Wyszyński podkreślał, że realizacja zadań macierzyńskich ma pierwszeństwo przed innymi. Pielęgnowanie życia rozumiał jako główne posłannictwo kobiety, która jest do tego powołana. Zaś do najważniejszych zadań kobiety matki wobec dziecka prymas zaliczał pełnienie macierzyństwa fizycznego (powołanie do życia i zaspokojenie podstawowych potrzeb fizycznych) i duchowego (wprowadzanie w świat porządku duchowego) ${ }^{15}$. Kardynał uważał, że dziecku najbardziej potrzebna jest matka, bo tylko ona ze swoimi predyspozycjami potrafi najwspanialej otoczyć opieką i miłością nowe życie, któremu daje początek. Rolę wychowawczą matki traktował jako jedyną i niepowtarzalną, odpowiedzialną za kształtowanie rodzinnej atmosfery ${ }^{16}$.

10 M. Sitarz, Zadania Kościoła względem narodu w nauczaniu Prymasa Wyszyńskiego, „Roczniki Nauk Prawnych”, T. XII, z.2, 2002, s. 32, cyt. za: Kościół w służbie Narodu, Rzym 1981, s. 18, 29.

11 S. Wyszyński, W hołdzie matkom narodu, Warszawa, Bazylika Świętojańska, 8 IX 1969, w: W sercu stolicy, S. Wyszyński, Rzym 1972, s. 128.

12 W. Gałązka, dz. cyt., s. 132.

13 A. Skreczko, Wktad kardynała Stefana, dz. cyt., s. 250, cyt. za: S. Wyszyński, Rodzina Bogiem silna, w: KPA, t. IX, s. 67.

14 M. Ozorowski, Stużebny charakter powołania kobiety, „Studia nad Rodziną”, 2001, R. 5, nr 2(9), s. 63.

15 Tenże, Kobieta-stużebnica w nauczaniu Stefana kardynała Wyszyńskiego, „Studia Teologiczne”, 19(2001) s. 84, cyt. za: S. Wyszyński, Niewiasta mężna, Warszawa 1964, s. 45.

16 J. Zabielski, Rodzina jako środowisko rozwoju religijno-moralnego w nauczaniu kardynała Stefana Wyszyńskiego, „Studia Prymasowskie”, 4(2010), s. 283-288, cyt. za: Por. S. Wyszyński, Apel do rodzin katolickich, w: tenże, Wielka Nowenna Tysiąclecia, s. 247. 
Wyszyński nie ograniczał roli kobiety wyłącznie do macierzyństwa. Wręcz przeciwnie, uważał, że kobieta jest równa mężczyźnie ${ }^{17}$, a więc tak, jak i on ma prawo realizować się również w innych wymiarach, np. zawodowym. Jednocześnie wskazywał na problem przeciążenia ról, który ma miejsce w sytuacji łączenia pracy zawodowej z macierzyństwem. Rozwiązania tej sytuacji kardynał nie postrzegał przez pryzmat rezygnacji z pracy zawodowej kobiet, ale wskazywał konkretne rozwiązania tego problemu, jak chociażby pełnego wynagrodzenia za pracę na pół etatu, a pracę domową i opiekę nad dzieckiem zaliczać jako jej drugą część. Twierdził, że dopiero po zrealizowaniu tego projektu „będzie sprawiedliwość wobec świata kobiecego"18.

Realizacja zadań macierzyńskich nie powinna dokonywać się w pojedynkę, a wręcz przeciwnie, wymaga dobrej współpracy z ojcem dziecka „Mąż i żona muszą wszystko uczynić, ażeby między nimi nie było rozdźwięku. W Najświętszej Rodzinie Maryja i Józef dali nam przykład jedności, ofiary i poświęcenia, oddając wszystko dla Dziecięcia Bożego, Jezusa Chrystusa" ${ }^{19}$. Podkreślał, że obecność ojca $\mathrm{w}$ procesie wychowania jest praktycznie niemożliwa do zastąpienia ${ }^{20}$. Z nauczania Prymasa Tysiąclecia możemy odczytać, że rola ojca koncentruje się głównie na odpowiedzialności ${ }^{21}$. Wspólnie z matką odpowiedzialny jest za wychowanie swojego dziecka, przekaz wartości i zasad moralnych, ochronę go przed niebezpieczeństwem ${ }^{22}$.

Ojcostwo rozpatrywać można z perspektywy biologicznej, fizycznej, duchowej. Można je odczytywać również z perspektywy religijnej, jako powołanie mężczyzny do ojcostwa. Takie rozpatrywanie ojcostwa było obecne w myśli kardynała Wyszyńskiego, który odnosił je do zamysłu Bożego zawartego na kartach Pisma Świętego, jak również do nauczania Magisterium Kościoła katolickiego ${ }^{23}$ i nazywa wielką tajemnicą. Mawia: „nie do nas należy wybór ojca (...). Tajemnicę tę zrozumiemy dopiero w życiu przyszłym”24. Jednocześnie podkreślał, że „ojcostwo

17 M. Ozorowski, Stużebny charakter powołania, dz. cyt., s. 63.

18 M. Braun-Gałkowska, Kobieta we współczesnym społeczeństwie polskim wedtug prymasa Stefana Wyszyńskiego, „Roczniki Nauk Społecznych”, T. X, 1982, s. 40, cyt. za: Przemówienie do członków ,Odrodzenia” z 17.2.1979.

19 A. Skreczko, Wkład kardynała Stefana, dz. cyt., s. 250, cyt. za: S. Wyszyński, Rodzina Bogiem silna, w: KPA, t. IX, s. 71.

20 A. Skreczko, Religijny wymiar ojcostwa wedlug Kardynała Stefana Wyszyńskiego, „Studia Teologiczne”, 38(2020), s. 110, cyt. za: Por. J. Witczak, Ojcostwo bez tajemnic, Warszawa 1987, s. 16.

21 Z. Struzik, Rodzina Bogiem silna moca swego narodu": Nauczanie o rodzinie kard. S. Wyszyńskiego, „Kultura Media Teologia” 3, 2010, s. 112.

22 S. Wyszyński, Uświęcenie pracy zawodowej, Société d’Éditions Internationales, Paryż 1963, s. 77.

23 A. Skreczko, Religijny wymiar ojcostwa, dz. cyt., s. 97, cyt. za: S. Wyszyński, O katolickiej woli zycia, Lublin 1947, LPP, s. 61.

24 Tamże, s. 632. 
jest wielkim zaszczytem, wielkim dowodem zaufania Boga. Wszelkie bowiem ojcostwo na ziemi pochodzi z ojcostwa Bożego, a pełnienie obowiązków ojca tak bardzo upodabnia do ojcostwa Bożego, że jesteśmy przekonani, iż rodzice są dla nas wyrazicielami woli Bożej"25. Wyszyński podkreślał, że ojcostwo ziemskie niejako wyrasta z głębi ojcostwa Bożego ${ }^{26}$.

Wyszyński utrzymywał, że każdy ojciec powinien wypracować w sobie cechy ojcowskiej miłości, do których zaliczał sprawiedliwość, roztropność, męstwo, wierność, cierpliwość, pracowitość, gotowość obrony rodziny przed grożącymi niebezpieczeństwami ${ }^{27}$. Prymas Tysiąclecia proponował model ojcostwa pełnego zaangażowania, poświęcenia siebie, swoich planów i marzeń, w pełnej miłości opiece nad dziećmi i ich matką na wzór świętego Józefa, którego ojcowie powinni naśladować przede wszystkim w czynnym zaangażowaniu się w życie rodzinne, w pełnej miłości opiece nad dziećmi i ich matką ${ }^{28}$.

\section{ZNACZENIE RODZINY W ŻYCIU NARODOWYM I SPOEECZNYM W NAUCZANIU KARDYNAEA STEFANA WYSZYŃSKIEGO}

Wyszyński przejawiał autentyczną troskę o rodzinę. Troska ta wynikała $\mathrm{z}$,pasterskiej odpowiedzialności i głębokiego patriotyzmu, które podpowiadały mu, że bez rodziny nie ma przyszłości narodu" ${ }^{29}$. Rodzina, zdaniem Prymasa Tysiąclecia, była największą siłą narodu i jednocześnie gwarancją jego przetrwania. Uważał, że w procesie wychowania rodzina jest społecznością pierwszą, ale nie jest jedyną. Do pozostałych zaliczał: naród, państwo, szkołę i kościół, powierzając im również oddziaływanie wychowawcze - lecz w odróżnieniu od rodziny - pomocnicze ${ }^{30}$. Owe społeczności nazywał „władzami wychowawczymi”, które przyjmują na siebie obowiązek współdziałania w służbie każdemu człowiekowi, zwłaszcza temu najmniejszemu i bezbronnemu.

Alina Rynio przedstawiła w sposób syntetyczny podejście kardynała Stefana Wyszyńskiego do wychowania rozumianego jako (...) „praca nad człowiekiem przy współudziale jego samego jako osoby będącej na etapie dojrzewania i rozwoju"31. Do wartości fundamentalnych, jakie przekazuje rodzina w wychowaniu

Tamże, s. 61.

S. Wyszyński, Uświęcenie pracy zawodowej, dz. cyt., s. 73.

27 A. Skreczko, dz. cyt., s. 105.

28 Tamże, cyt. za: S. Wyszyński, Radości Polski Tysiaclecia, Sochaczew 18.03.1966, KPP, t. XXIII 1966, s. 70.

29 Z. Struzik, Rodzina Bogiem silna, dz. cyt., s. 106.

30 Tamże, s. 107.

31 A. Rynio, Wychowanie młodzieży w nauczaniu Kardynała Stefana Wyszyńskiego, Redakcja Wydawnictw KUL, Lublin 2010, s. 12. 
Prymas Tysiąclecia zaliczył ideały i wartości, które dojrzewają w człowieku i stanowią o jego duchowym bogactwie oraz wierzenia religijne ${ }^{32}$. Podkreślał też potrzebę wielostronnego wychowania dziecka, wskazując na konieczność wychowania zarówno w aspekcie fizycznym, duchowym, rodzinnym, narodowym, intelektualnym i społecznym ${ }^{33}$.

Rodzinę traktował jako podstawowy element w budowaniu trwałości narodu i w związku z tym uważał, że powinna mieć rolę uprzywilejowaną w życiu narodowo-państwowym ${ }^{34}$. Wielokrotnie podkreślał, że państwo jako jedyny pracodawca, powinno prowadzić politykę rodzinną. Rodzinę traktował jako fundament życia państwowego, na którym państwo powinno opierać swoją politykę gospodarczą ${ }^{35}$. Prymas podkreślał, że prawo rodziny do wychowania dzieci jest niepodważalnym i niezbywalnym prawem rodziców. Szczególną uwagę przypisywał kształtowaniu osoby przez rodzinę, gdyż jako najmniejsza komórka społeczna ma istotny wpływ na kształtowanie osobowości, umożliwia człowiekowi uczestnictwo w społeczności narodowej i państwowej: „Rodzina uzdalnia człowieka nie tylko do życia fizycznego, ale i do współżycia społecznego. Z rodziny bowiem człowiek wynosi początek moralnych i społecznych pojęć, które kształcą jego osobę"36. Podkreślał, że rodzina jest społecznością starszą niż państwo. Cel rodziny przekracza cel państwa, które to nie może prowadzić do łamania praw rodziny. Wskazywał na obopólną zależność rodziny i państwa. Rodzina jest zależna od państwa, gdyż we właściwym wychowaniu potrzebuje od niego pomocy. Podkreślić należy fakt, że rodzina jest w stanie istnieć bez państwa. Natomiast państwo zależne jest od rodziny, gdyż otrzymuje od niej obywateli. Państwo nie może istnieć bez rodziny ${ }^{37}$, ,gdyż naród powstaje z rodzin. Rodziny piastują w swoich dłoniach losy narodów" 38 .

32 Z. Struzik, Rodzina w obronie życia, wolności i wiary w nauczaniu ks. kardynała Stefana Wyszyńskiego Prymasa Polski, Instytut Papieża Jana Pawła II, Warszawa 2018, s. 80, cyt. za: S. Wyszyński, Co rodzina daje państwu?, „Ład Boży” R. 2 (1946), nr 1, s. 3.

33 A. Skreczko, Religijny wymiar ojcostwa, dz. cyt., s.110, cyt. za: S. Wyszyński, W sprawie katolickiego wychowania młodzieży. Do rodziców, Gniezno, 5.10.1950, LPP, s. 173.

34 J. Koperek, Naród i państwo w myśli społecznej kardynała Stefana Wyszyńskiego i Jana Pawła II, „Studia Elbląskie 11”, 2010, s. 184-185.

35 Tamże, s.184.

36 Z. Struzik, Rodzina w obronie życia, dz. cyt., s. 80, za: S. Wyszyński, Co rodzina daje państwu?, dz. cyt., s. 3 .

37 Z. Struzik, Rodzina Bogiem silna, dz. cyt., s. 116; por. Z. Micewski, „Kościót-naród-państwo” w myśli Stefana kardynała Wyszyńskiego, w: Wspomnienia o Stefanie kardynale Wyszyńskim, red. B. Piasecki, A. Rastawicki, Kraków 2001, s. 140-151; S. Wyszyński, Kościół w stużbie narodu, Rzym 1981, s. 9.

38 S. Wyszyński, W sprawie wizytacji pasterskiej, Warszawa, Boże Narodzenie 1950; W. Karasiński, Rodzina w świetle nauczania ks. Stefana Wyszyńskiego: na podstawie artykułów w , Ładzie Bożym” w latach 1945-1946, „Studia Włocławskie” 5, 2002, s. 341-343. 
Wyszyński podkreślał również, że prawa rodziny powinny być szanowane, wspomagane i chronione zarówno przez państwo, jak i przez Kościół, zarówno w dziedzinie poglądów, jak i w sprawach gospodarczych i socjalnych. Państwo powinno być skierowane ku rodzinie, być państwem rodzinnym, gdyż poszanowanie jej praw musi być początkiem wszelkiej reformy życia społecznego ${ }^{39}$. Ograniczenie praw rodziny prowadzić może do poważnych konsekwencji dla tożsamości duchowej i kulturowej narodu, ograniczać podstawy autonomii rodziny. Owe zagrożenia rodziny wywoływały u prymasa niepokój, a zarazem wezwanie do odpowiedzialności narodu wobec rodziny, które to prowadziło do ukazywania słusznych i koniecznych rozwiązań społecznych. Jednym z możliwych sposobów realizacji praw rodziny - zdaniem Wyszyńskiego - jest chronienie trwałości i nierozerwalności związku małżeńskiego ${ }^{40}$.

Wyszyński w swoim nauczaniu wielokrotnie wskazywał na przysługujące rodzinie prawa, do których zaliczał prawo do prokreacji, wolności wychowania, prawo do godziwego bytu ${ }^{41}$ oraz prawo do kształtowania i przekazu wartości kulturowych ${ }^{42}$. Czesław Bartnik, na podstawie analizy nauczania społecznego kardynała Wyszyńskiego wskazuje szersze rozumienie praw przynależnych rodzinie, wymieniając: prawo do posiadania dzieci i skierowania świata rodziny ku dziecku w najwyższej miłości; prawo do wzajemnej służby sobie, bez sztucznych ograniczeń i barier; prawo do doskonalenia się poprzez rodzinę i całą rodziną; prawo do miłości, wierności, pełnego zaufania, sprawiedliwości, wolności od podejrzeń, możności otrzymania przebaczenia w przypadku żalu za winy; prawo do pełnej wspólnoty osób, dóbr, myśli, serc, czynów, historii, losów, tworzenia świata; prawo do pokoju, duchowej „,iszy”, azylu od świata zła i okrucieństwa, wolności od ogólnego zakłamania i zgiełku życia; prawo wolności do samowyrażenia swego życia, swobody rozwoju ducha, spełniania swej osobowości-rodzinnej; prawo do dobrej sławy rodzinnej, do zachowania i rozwoju tradycji swych ojców, do pamięci rodowej, wspólnego czucia przeszłości rodziny, prawo do tworzenia przez rodzinę jednego wspólnego theatrum vitae, theatrum familiae, niejako wspólnego, czystego ekranu i sumienia"43.

39 J. Krukowski, Zasada współdziałania między państwem a kościołem w ujęciu Prymasa Stefana Wyszyńskiego, „Rocznik Nauk Prawnych”, T. XII, z.1-2002, s.227.

40 J. Krukowski, dz. cyt., s. 227; M. Sitarz, dz. cyt. s. 32-33.

${ }^{41}$ O prawie do godziwego bytu pisał S. Wyszyński już w 1946 roku, w jednym ze swoich artykułów zamieszczonych w ,Ladzie Bożym”.

42 R. Iwan, Polska, ale jaka? Myśl społeczna Kardynała Stefana Wyszyńskiego, Lublin-Kolonia, 1993, s. 65.

${ }^{43} \mathrm{Cz}$. Bartnik ułożył tę kartę na podstawie kazań, listów pasterskich oraz takich pozycji K. Wyszyńskiego: W sercu Stolicy, Rzym 1972; Z gniazda orlą, Rzym 1972; W kierunku prawdy, Warszawa 1976; por. Cz. Bartnik, Chrześcijańska pedagogia narodowa wedtug S. Wyszyńskiego, w: Polska Teologia Narodu, red. Cz. Bartnik, Towarzystwo Naukowe Katolickiego Uniwersytetu Lubelskiego, Lublin 1986, s. 189. 


\section{WYCHOWANIE W RODZINIE \\ W UJECIU KARDYNALA STEFANA WYSZYŃSKIEGO}

Funkcjonowanie rodziny jako najmniejszej komórki społeczeństwa wymaga ładu i porządku społecznego, które zabezpieczać będą jej podstawowe prawa i obowiązki. Sytuacja analogiczna ma miejsce w rodzinie, w której ze względu na różnorodność zadań i funkcji, które pełni, istotne jest przestrzeganie ustalonej hierarchii praw i obowiązków. Wyszyński podkreślał, że w rodzinie musi istnieć ład życia rodzinnego, który jest podstawą ładu w państwie. Wskazywał na ścisły związek pomiędzy jakością życia rodzinnego a efektami wychowania ${ }^{44}$. Wyszyński postrzegał bowiem człowieka i rodzinę wielowymiarowo (m.in. w porządku religijno-moralnym, społecznym, ekonomicznym, politycznym, narodowym), przypominając jednocześnie, że wszystkie one niejako „łączą się” ze sobą w rodzinie i tam najpełniej się realizują. W rodzinie jednostka uczy się otwartości, akceptacji i odpowiedzialności za innych. Doświadcza, że życie jest największą wartością.

Wyszyński porównywał rodzinę do dzieła sztuki. Podobnie jak obraz tworzony przez artystę, rodzina tworzona jest z wielkim trudem. Prawdziwe dzieło sztuki wymaga bowiem wysiłku. Aby rodzina mogła być uznana za dzieło sztuki, wszyscy jej członkowie muszą się natrudzić. Wymaga ona zwycięstwa nad samym sobą każdego jej członka.

W swoim nauczaniu Wyszyński wiele miejsca poświęcił prawom człowieka. Wielokrotnie podkreślał, że nie są one przez nikogo nadane i nikt nie ma prawa ich odbierać. Dziecko nie jest własnością rodzica. Nikt też nie może zabierać życia drugiemu człowiekowi, zwłaszcza wtedy, gdy jest bezbronny. Przesłanie to odnosiło się głównie do dzieci: „Życie to własność człowieka, choćby najmniejszego. Dlatego też nikt nie ma prawa dysponowania tym życiem według własnego upodobania czy programu. Raz poczęte życie pod sercem matki - chociażby człowiek nie miał jeszcze wymiaru większego nad ziarnko fasoli - należy do Boga, do człowieka, do rodziny, do narodu" 45 .

Kardynał Wyszyński w swoim nauczaniu wiele miejsca poświęcił na ukazanie różnorodnych wzorców wychowawczych dotyczących rodziny, jej istoty i funkcji wychowawczych $^{46}$. Wychowanie dokonuje się w przestrzeni psychicznej, która jest jednocześnie naznaczona i ograniczona pewnymi znakami nakazu i zakazu. Przestrzeni, która stanowi barierę zabezpieczającą, nie pozwalając zachować się

44 M.A. Roszewski, dz. cyt. s. 146.

45 S. Wyszyński, Kazania Świętokrzyskie (1974-1976), wstęp i opracowanie R. Łatka, B. Mackiewicz, D. Zamiatała, IPN, Wydawnictwo Soli Deo, Warszawa 2021, s. 156.

46 J. Zabielski, dz. cyt., s.283. 
w sposób nieakceptowany przez przyjęte normy i społeczne zasady ${ }^{47}$. Wyszyński w rozważaniach o rodzinie wielokrotnie wskazywał na wzór Świętej Rodziny, która stanowić powinna wzór dla każdej rodziny chrześcijańskiej, mówiąc: „Rodzina Święta niech będzie waszym wzorem i wytrwaniem w szkole rodzinnej miłości" ${ }^{\prime 4}$.

Wyszyński w swoim nauczaniu kładł nacisk na kwestie wzoru i własnej postawy rodziców w wychowaniu dzieci. Twierdził, że zasadą wychowania jest zasada życia w prawdzie ${ }^{49}$. Odczytać to możemy jako zgodność słów z czynami (konkretnym zachowaniem). Nie wystarczy bowiem deklarować pewnych wartości w życiu, ale żyć według tychże wartości. Nie wystarczy więc głoszenie prawdy, trzeba według niej żyć. Kardynał był zdania, że rodzicielskie doświadczenie ma wpływ na sferę psychiczną dziecka, na jego przyszłość. Wskazywał, że bezpośrednim czynnikiem determinującym przyszłość dziecka jest „geniusz” rodziców rozumiany jako okazywana dziecku życzliwość, uwaga, niezawodność, czułość. Wielokrotnie zadawał sobie pytanie, czy przekaz tego rodzicielskiego „geniuszu” nie będzie zagrożony. Wątpliwości wynikały z oglądu ówczesnego świata, tempa życia społecznego, nieustannego zabiegania i chronicznego braku czasu. Wyrażał obawy, że dziecko nie doświadczy tego daru w rodzinnym gronie i w konsekwencji świat uczuć i wartości pozostanie zamkniętym wymiarem osobistego doświadczenia $^{50}$. Prymas Tysiąclecia podkreślał, że rodzina stanowiąc naturalną społeczność, w sposób bezpośredni kształtuje zachowanie dziecka począwszy od jego pierwszych chwil przyjścia na świat. W rodzinie i jej naturalnym charakterze (jako jednostki społecznej) pokładał nadzieje, traktując ją jako wspólnotę miłości, która przekazuje wartości niezbędne do osobowego rozwoju człowieka ${ }^{51}$. Prymas Tysiąclecia mawiał: „Rodziny pamiętajcie! Przyszła wasza godzina! Jesteśmy w tak trudnym położeniu, że często nie wiemy, jakich sił szukać, na jakiej skale się oprzeć. Jesteśmy wśród lotnych piasków, zmieniających się sytuacji i koniunktur i nie znajdziemy dla kultury chrześcijańskiej innego oparcia, jak tylko zdrową rodzinę" 52 .

Wyszyński podkreślał również, że wychowanie nie jest możliwe bez samowychowania. Wielokrotnie dawał temu wyraz w swoich treściach, iż nie można stać się dojrzałym i dobrze wychowanym bez własnego i świadomego udziału w pro-

47 M.A. Roszewski, dz. cyt., s. 151.

48 A. Skreczko, Religijny wymiar ojcostwa, dz. cyt., s. 101 za: Stowo duszpasterskie na uroczystość Świętej Rodziny, S. Wyszyński, 08.01.1967, LPP, s. 534.

49 A. Skreczko, dz. cyt., s. 174.

50 M.A. Roszewski, dz. cyt., s. 150-151.

51 J. Zabielski, dz. cyt., s. 283-284.

52 A. F. Dziuba, Kultura chrześcijańska w przepowiadaniu kardynała Stefana Wyszyńskiego, prymasa Polski, „Studia Prymasowskie” 2, 2008, s. 178, cyt. za: S. Wyszyński, Rodzice, nadeszła wasza godzina, w: tenże, Wielka Nowenna Tysiaclecia, Paryż 1962, s. 227. 
cesie wychowania. Samowychowanie rozumiane jest w kontekście teologicznym jako praca nad sobą, co do której człowiek został wyposażony w odpowiednie dyspozycje. Kardynał Wyszyński twierdzi, że skuteczność wychowania w znacznej mierze zależy od samego wychowanka, który jest pobudzany i aktywizowany do wyboru oraz współtworzenia dobra. Samowychowanie ma służyć do motywacji działania i rozwoju wewnętrznej siły, która tkwi w każdym człowieku. Wyszyński wskazywał również na związek samowychowania z różnymi formami wychowania (fizycznym, umysłowym, moralnym, społecznym, estetycznym itd.) i czynnikami osobowymi, do których zaliczał samopoznanie, samoocenę moralną, samokontrolę, transcendencję osoby. Podkreślał konieczność „uruchomienia” pracy własnej. Prymasowskie głoszenie prawdy o Bogu, człowieku i świecie można uznać za jeden ze sposobów wspierania pracy nad sobą ${ }^{53}$. Zwracał również uwagę na wzmacniającą wartość doświadczeń osobistych każdej jednostki zmagającej się o sprawiedliwość i dobro, a odkrycie dobra wydaje się być podstawą do pracy nad sobą. Dobro, jak podkreśla A. Rynio, dookreślone zostało w ,ideałach, wartościach i wzorach dających możliwość wnikliwego i surowego poznania i konfrontowania rzeczywistego obrazu siebie" ${ }^{54}$.

Praca nad sobą, zdaniem Wyszyńskiego, powinna zmierzać w kierunku poznania swojej wady głównej (słabych stron - dop. M.L.), by poprzez jej wyeliminowanie móc poprawnie budować pozytywne sprawności poszczególnych cnót. Szczególne znaczenie w pracy nad samym sobą przypisywał prymas pracy, rozpatrując ją jako jeden z istotnych czynników determinujących proces wychowawczy, jak i samowychowawczy. Wskazywał, w jaki sposób praca wyraża człowieka. Rozumiał ją nie tylko jako działanie gospodarcze i produkcyjne, ale także jako twórczość umysłową, kulturalną, religijną i kontemplacyjną. Praca umożliwiająca również zaspokojenie fizycznych potrzeb człowieka. Ma wartość zarówno indywidualną, jak i społeczną. Dzięki niej dokonuje się kontakt międzyosobowy i wymiana wartości. Praca zdaniem Wyszyńskiego powinna zawsze prowadzić do doskonalenia człowieka. Taki wymiar stanowiła metoda budzenia odpowiedzialności przez dokonywanie refleksji nad dotychczasowym życiem i samym sobą. Kładł więc istotny nacisk na rozwijanie osobowości człowieka, a w pracy nad sobą zachęcał do specjalnego wysiłku ${ }^{55}$.

Wyszyński przypomina, że rodzice nie wychowują dzieci tylko dla siebie, ale także dla dobra społecznego ${ }^{56}$. Wskazywał, że rodzice mają równe prawa i obowiązki w rodzinie wobec dzieci, których rozwój będzie niezakłócony, gdy oboje będą w sposób zgodny i przepełniony miłością współdziałać w wychowaniu

\footnotetext{
53 A. Rynio, Samowychowanie metoda skutecznego wychowania w nauczaniu kardynata Stefana Wyszyńskiego, „Roczniki Nauk Społecznych”, T. XXIII, z. 2, 1995, s. 27-28.

54 Tamże, s. 29.

55 A. Rynio, dz. cyt., s. 35-38.

56 W. Karasiński, dz. cyt., s. 341.
} 
dziecka $^{57}$. Prymas Tysiąclecia wskazywał rodzicom jeszcze inną zasadę - zasadę jednoczenia w miłości i dobroci. Wskazując, że nie są to proste zasady, twierdził, że czasami trzeba dać więcej niż się posiada. Człowiek więc musi nieustannie przekraczać siebie. Rodzice zaś muszą nieustannie pracować nad własną relacją miłości, która jest obustronnym obowiązkiem. Podobnie jak zasada wierności ${ }^{58}$. Wychowanie pozbawione miłości sprawia, że rozwój dziecka „będzie powoli umierać, gdyż prawdziwe życie jest tylko tam, gdzie jest miłość" ${ }^{9}$. Wyszyński dostrzegał u rodziców wyraźny kult ciała i umysłu, kosztem licznych zaniedbań w sferze wychowania religijnego, które uważał za integralny element wychowania, którego nie rozumiał wyłącznie jako udzielanie ,pomocy w procesie kształtowania i pogłębiania nadprzyrodzonej wiary w Boga, lecz również w pogłębianiu szacunku dla szeroko rozumianych wartości ogólnoludzkich"60.

\section{PODSUMOWANIE}

W nauczaniu społecznym Wyszyński podkreślał potrzebę i zasadę porządku społecznego, w którym pierwsze miejsce zajmuje rodzina i jej dobro. W rodzinie zaś najważniejszy jest człowiek, którego życiowym kwantyfikatorem jest miłość jako „najlepsza szkoła sumienia i sumienności wobec Boga i bliźnich”"61.

Rozważając aktualność myśli Prymasa Tysiąclecia należy je dostrzegać na tle wszystkich zjawisk i procesów, które współcześnie wpływają na dezintegrację rodziny. Prymas Polski dostrzegał te trudności i niebezpieczeństwa, na jakie napotykało życie rodzinne w ówczesnej sytuacji społecznej i dlatego niestrudzenie walczył o prawa rodziny oraz o warunki jej prawidłowego rozwoju. Nie tylko wskazywał na te wszystkie zagrożenia, jakie wynikały z głoszonej ideologii, ze struktur społecznych i administracyjnych, z systemu społeczno-ekonomicznego oraz z konkretnych sytuacji gospodarczych, ale organizował i prowadził systematyczną akcję duszpasterstwa rodzinnego w różnych jego formach i na różnych płaszczyznach. Prymas Wyszyński przypomina, że człowiek, ze swej natury, ma

57 A. Skreczko, dz. cyt., s. 250 za: Matka Boga w codziennym życiu ludzkim, S. Wyszyński, w: KPA, t. XV, s. 31-44.

58 A. Skreczko, s dz. cyt.,. 175.

59 W. Krupiński, Wychowywać miłościa, Wydawnictwo WAM, Kraków 1999, s. 51.

60 M.A. Roszewski, dz. cyt., s. 153.

${ }^{61}$ J. Zabielski, dz. cyt., s. 294, cyt. za: S. Wyszyński, Sumienie prawe u podstaw odnowy życia narodowego, w: tenże, Kościół w stużbie narodu, Poznań-Warszawa 1981, s. 138; por. J. Zabielski, Społeczno-moralne zagrożenia narodu polskiego w nauczaniu kardynała Stefana Wyszyńskiego, „Studia Prymasowskie”, 2(2008), s. 349-364. 
potrzebę bycia $\mathrm{z}$ innymi i dla innych. Jedynie w ten sposób potrafi się w pełni rozwinąć i osiągnąć szczęście ${ }^{62}$.

Propozycje wysuwane przez prymasa Wyszyńskiego w odniesieniu do wychowania społecznego były nie tylko odpowiedzią na wyzwania charakterystyczne dla tamtej epoki, ale są ważne również dzisiaj, w rzeczywistości deprecjonującej istotne wartości życia ludzkiego, patrzącej na wychowanie społeczne często w sposób wypaczony. Podobnie jak wówczas, także i dzisiaj rodzina przeżywa wielostronne sytuacje kryzysowe. Rodzice, ponieważ dali dziecku życie, zobowiązani są to życie wychować zarówno w płaszczyźnie fizycznej, jak i duchowej. Rola rodziców w wychowaniu jest pierwszorzędna i niezaprzeczalna, zaś instytucje państwowe i kościelne powinny wspierać ich w procesie nauczania i wychowania swoich dzieci zgodnie z własnymi przekonaniami ${ }^{63}$. Ogólny normatyw bronienia rodziny sformułował następująco: „Rodzice mają także obowiązek stawać w obronie praw swej rodziny i własnych dzieci, a szczególnie prawa do wychowania ich według własnego światopoglądu" ${ }^{4}$. Kardynała Stefana Wyszyńskiego zaliczyć z pewnością możemy do jednego z największych obrońców wartości rodziny.

\section{Bibliografia}

Braun-Gałkowska M., Kobieta we współczesnym społeczeństwie polskim wedtug prymasa Stefana Wyszyńskiego, „Roczniki Nauk Społecznych”, T. X, 1982.

Dziekoński S., Wychowanie społeczne w nauczaniu kardynała Stefana Wyszyńskiego, „Studia Prymasowskie”, 5, 2011.

Dziuba A.F., Kultura chrześcijańska w przepowiadaniu kardynała Stefana Wyszyńskiego, prymasa Polski, „Studia Prymasowskie”2, 2008, cyt. za: S. Wyszyński, Rodzice, nadeszła wasza godzina, w: tenże, Wielka Nowenna Tysiąclecia, Paryż 1962.

Iwan R., Polska, ale jaka? Myśl społeczna Kardynała Stefana Wyszyńskiego, Lublin-Kolonia, 1993.

Karasiński W., Rodzina w świetle nauczania ks. Stefana Wyszyńskiego: na podstawie artykułów w , Ładzie Bożym” w latach 1945-1946, „Studia Włocławskie", 5, 2002.

Koperek J., Naród i państwo w myśli społecznej kardynała Stefana Wyszyńskiego i Jana Pawta II, „Studia Elbląskie 11”, 2010.

62 S. Dziekoński, Wychowanie społeczne w nauczaniu kardynała Stefana Wyszyńskiego, „Studia Prymasowskie," 5, 2011, s.153-154.

63 A. Romanko, Podmioty zobowiazane do wychowania dziecka wedtug Stefana Kardynała Wyszyńskiego. Wybrane zagadnienia, „Kościół i Prawo”, 8(21) 2019, nr 1, s. 57.

${ }^{64}$ Por. S. Wyszyński, Prymat człowieka w tadzie społecznym, Londyn 1976, s. 99. 
Krukowski J., Zasada współdziałania między państwem a kościołem w ujęciu Prymasa Stefana Wyszyńskiego, „Rocznik Nauk Prawnych”, T. XII, z.1-2002.

Krupiński W., Wychowywać miłościa, Wydawnictwo WAM, Kraków 1999.

Lewandowski J., Naród w nauczaniu Kardynała Stefana Wyszyńskiego. Warszawa 1985.

Gałązka W., Małżeństwo i rodzina w nauczaniu kardynała Stefana Wyszyńskiego, „Studia Prymasowskie”, 4 (2010).

Micewski Z., „Kościót-naród-państwo” w myśli Stefana kardynata Wyszyńskiego, w: Wspomnienia o Stefanie kardynale Wyszyńskim, red. B. Piasecki, A. Rastawicki, Kraków 2001.

Ozorowski M., Kobieta-stużebnica w nauczaniu Stefana kardynała Wyszyńskiego, „Studia Teologiczne”, 19(2001), cyt. za: S. Wyszyński, Niewiasta mężna, Warszawa 1964.

Ozorowski M., Stużebny charakter powołania kobiety. „Studia nad Rodziną”, 2001, R. 5, nr 2(9).

Polska Teologia Narodu, Towarzystwo Naukowe Katolickiego Uniwersytetu Lubelskiego, red. C. Bartnik, Lublin 1986.

Romanko A., Podmioty zobowiązane do wychowania dziecka wedtug Stefana Kardynała Wyszyńskiego. Wybrane zagadnienia, „Kościół i Prawo”, 8(21) 2019, nr 1.

Roszewski M.A., Wizja wychowania w wymiarze nauczania społecznego Prymasa Stefana Kardynała Wyszyńskiego, „Teologia i Człowiek”, 10 (2007).

Rynio A., Samowychowanie metoda skutecznego wychowania w nauczaniu kardynała Stefana Wyszyńskiego, „Roczniki Nauk Społecznych”, T. XXIII, z. 2, 1995.

Rynio A., Wychowanie młodzieży w nauczaniu Kardynała Stefana Wyszyńskiego, Redakcja Wydawnictw KUL, Lublin 2010.

Sitarz M., Zadania kościoła względem narodu w nauczaniu Prymasa Wyszyńskiego, „Roczniki Nauk Prawnych”, T. XII, z.2, 2002, cyt. za: Kościót w stużbie Narodu, Rzym 1981.

Skreczko A., Religijny wymiar ojcostwa wedtug Kardynała Stefana Wyszyńskiego, „Studia Teologiczne”, 38(2020).

Skreczko A., Rodzicielstwo jako dar i zadanie na podstawie nauczania Prymasa Stefana Wyszyńskiego podczas Wielkiej Nowenny Tysiąclecia, „Rocznik Teologii Katolickiej", T. V, 2006.

Skreczko A., Troska Prymasa Tysiąclecia o rodzinę polska, ,Rocznik Teologii Katolickiej", T. 1, 2002.

Skreczko A., Wkład kardynała Stefana Wyszyńskiego w organizację duszpasterstwa kobiet, „Studia Prymasowskie” 4, 2010, cyt. za: S. Wyszyński, Parafia i rodzina katolicka na stużbie religijnego wychowania młodego pokolenia, w: KPP, t. IX. 
Struzik Z., Rodzina Bogiem silna moca swego narodu: Nauczanie o rodzinie kard. S. Wyszyńskiego, „Kultura Media Teologia”, 3, 2010.

Struzik Z., Rodzina w obronie życia, wolności i wiary w nauczaniu ks. kardynała Stefana Wyszyńskiego Prymasa Polski, Instytut Papieża Jana Pawła II, Warszawa 2018.

Wyszyński S., Rodzice! Nadeszła Wasza godzina, Jasna Góra, 15.08.1961, KPA, t. 9 .

Wyszyński S., Kazania Świętokrzyskie (1974-1976), wstęp i opracowanie R. Łatka, B. Mackiewicz, D. Zamiatała, IPN, Wydawnictwo Soli Deo, Warszawa 2021.

Wyszyński S., Prymat człowieka w tadzie społecznym, Londyn 1976.

Wyszyński S., Uświęcenie pracy zawodowej, Société d'Éditions Internationales, Paryż 1963.

Wyszyński S., W hołdzie matkom narodu, Warszawa, Bazylika Świętojańska, 8 IX 1969, w: W sercu stolicy, S. Wyszyński, Rzym 1972.

Wyszyński S., W sprawie wizytacji pasterskiej, Warszawa, Boże Narodzenie 1950.

Zabielski J., Rodzina jako środowisko rozwoju religijno-moralnego w nauczaniu kardynała Stefana Wyszyńskiego, „Studia Prymasowskie”, 4(2010).

Zabielski J., Społeczno-moralne zagrożenia narodu polskiego w nauczaniu kardynała Stefana Wyszyńskiego, „Studia Prymasowskie” 2(2008). 